\title{
Multi objective optimization of window to wall ratio of University Gymnasium in severe cold area by coupling natural lighting and energy consumption
}

\author{
ZongJunlin ${ }^{1}$ ZhangLongwei $^{1}{ }^{\text {, * }}$ \\ ${ }^{1}$ School of architecture and planning, Shenyang Jianzhu University, China
}

\begin{abstract}
Objective To explore the relationship between window opening ratio and natural lighting and energy consumption of University Gymnasiums in severe cold area, and put forward optimization strategies. Methods Digital simulation technology was used to simulate the energy consumption and natural lighting of University Gymnasium window opening ratio, and the window opening scheme with natural lighting and low energy consumption was obtained. Conclusion The side window lighting should be used in the window opening scheme of small and medium-sized university gymnasiums. Within the range of experimental data, the North-South lighting is the main lighting mode, and the East-West lighting is the auxiliary.
\end{abstract}

\section{Construction of typical information model}

\subsection{Establishment of general model of University Gymnasium in cold regions}

With the reform and development of China's higher education, the scale of higher education is gradually expanding, and the cultivation of students' sports quality has been widely valued. Gymnasium has gradually become one of the indispensable components of the architectural group in colleges and universities. Due to the large building volume, the energy consumption and the operation and maintenance costs of various facilities in the process of using the stadium are far higher than expected ${ }^{[1-3]}$. In recent years, with the wide application of digital technology in green design, the single building performance analysis of building energy consumption, such as natural lighting and lighting ventilation, has gradually developed into a multi-objective building performance evaluation. For example, the paper for Zhang on Bin ${ }^{[4]}$ aimed at urban buildings in Beijing, aiming at lighting coefficient, visual comfort and building heat consumption, This paper studies the optimization of the window form of residential buildings in the city. There are also similar simulation experiments that aim at building cluster shape, Da, UDI and various energy consumption, such as , Liu Yao ${ }^{[5]}$, sun Cheng ${ }^{[6]}$, etc. In this paper, grasshopper parametric modeling, ladybug \& honeybee energy consumption simulation tools are used. On this basis, the multi-objective optimization tool octopus is used to optimize the window wall ratio of typical university. The natural lighting and energy consumption coupling optimization is carried out, and the window design strategy of University Gymnasiums considering both natural lighting and energy consumption is summarized, It provides a theoretical basis for the natural light environment optimization and low energy consumption design of large space buildings in cold regions.

Gymnasium is a typical large space building, which is obviously different from other general education buildings in space scale, function and structure. In order to get more information about the characteristics of University gymnasiums, the author systematically combs 20 famous University Gymnasiums built in recent years in severe cold areas in China, as shown in Table 1.

Table1. Survey data of University Gymnasium

\begin{tabular}{|c|c|c|c|c|c|c|c|c|}
\hline $\begin{array}{c}\text { Region } \\
\text { (province) }\end{array}$ & Building name & Scale & $\begin{array}{c}\text { The measure } \\
\text { of area } \\
\left(\mathrm{m}^{2}\right)\end{array}$ & $\begin{array}{c}\text { height } \\
(\mathrm{m})\end{array}$ & $\begin{array}{c}\text { Number } \\
\text { of seats } \\
(\text { seats })\end{array}$ & $\begin{array}{c}\text { Natural } \\
\text { lighting }\end{array}$ & $\begin{array}{c}\text { Architectural } \\
\text { form }\end{array}$ & $\begin{array}{c}\text { Site } \\
\text { size } \\
(\mathrm{m})\end{array}$ \\
\hline \multirow{7}{*}{ Liaoning } & $\begin{array}{c}\text { Shenyang University } \\
\text { Gymnasium }\end{array}$ & $\begin{array}{c}\text { Medium- } \\
\text { sized }\end{array}$ & 18900 & - & 5000 & $\begin{array}{c}\text { Side } \\
\text { window }\end{array}$ & Rectangle & \\
\cline { 2 - 9 } & $\begin{array}{c}\text { Liaoning University } \\
\text { Gymnasium }\end{array}$ & $\begin{array}{c}\text { Medium- } \\
\text { sized }\end{array}$ & 16500 & 17.5 & 4000 & $\begin{array}{c}\text { Side } \\
\text { window }\end{array}$ & Cylinder & \\
\cline { 2 - 9 } & $\begin{array}{c}\text { Shenyang Jianzhu } \\
\text { University }\end{array}$ & $\begin{array}{c}\text { Medium- } \\
\text { sized }\end{array}$ & 14000 & 19.4 & 1600 & $\begin{array}{c}\text { Skylights } \\
\text { and side }\end{array}$ & Rectangle & $54 \times 32$ \\
\hline
\end{tabular}

*Corresponding author: z_lw@sjzu.edu.cn 


\begin{tabular}{|c|c|c|c|c|c|c|c|c|}
\hline & $\begin{array}{l}\text { Northeast University } \\
\text { Gymnasium }\end{array}$ & Small-scale & 11000 & 17.2 & 1500 & $\begin{array}{c}\text { Side } \\
\text { window }\end{array}$ & Ellipse & \\
\hline & $\begin{array}{l}\text { Shenyang University of } \\
\text { Technology Gymnasium }\end{array}$ & $\begin{array}{l}\text { Medium- } \\
\text { sized }\end{array}$ & 13000 & 22 & 4644 & $\begin{array}{c}\text { Side } \\
\text { window }\end{array}$ & Ellipse & $42 \times 55$ \\
\hline & $\begin{array}{c}\text { Gymnasium of Dalian } \\
\text { University of Technology }\end{array}$ & $\begin{array}{l}\text { Medium- } \\
\text { sized }\end{array}$ & 17000 & 25 & 5800 & $\begin{array}{c}\text { Side } \\
\text { window }\end{array}$ & $\begin{array}{l}\text { Ellipse、 } \\
\text { rectangle }\end{array}$ & $39 \times 25$ \\
\hline \multirow{4}{*}{ Jilin } & $\begin{array}{c}\text { Jilin University } \\
\text { Gymnasium }\end{array}$ & $\begin{array}{l}\text { Medium- } \\
\text { sized }\end{array}$ & 36000 & 24 & - & $\begin{array}{c}\text { Side } \\
\text { window }\end{array}$ & $\begin{array}{l}\text { Circular、 } \\
\text { rectangle }\end{array}$ & \\
\hline & $\begin{array}{c}\text { Gymnasium of } \\
\text { Changchun Institute of }\end{array}$ & $\begin{array}{l}\text { Medium- } \\
\text { sized }\end{array}$ & 11000 & 17.6 & 2700 & $\begin{array}{c}\text { Side } \\
\text { window }\end{array}$ & Rectangle & \\
\hline & $\begin{array}{c}\text { Jilin University of } \\
\text { architecture Gymnasium }\end{array}$ & Small-scale & - & 22 & 2300 & $\begin{array}{c}\text { Side } \\
\text { window }\end{array}$ & Rectangle & \\
\hline & $\begin{array}{c}\text { Gymnasium of } \\
\text { Changchun University of } \\
\text { traditional Chinese }\end{array}$ & Small-scale & - & 19 & 800 & $\begin{array}{c}\text { Side } \\
\text { window }\end{array}$ & Rectangle & \\
\hline \multirow{4}{*}{ Heilongjiang } & $\begin{array}{c}\text { Harbin Institute of } \\
\text { Technology Gymnasium }\end{array}$ & Small-scale & 7500 & & 3000 & $\begin{array}{l}\text { Skylights } \\
\text { and side }\end{array}$ & $\begin{array}{l}\text { Irregular } \\
\text { rectangle }\end{array}$ & $61 \times 30$ \\
\hline & $\begin{array}{l}\text { Gymnasium of Harbin } \\
\text { University of science and }\end{array}$ & $\begin{array}{l}\text { Medium- } \\
\text { sized }\end{array}$ & 33000 & 22 & 2700 & $\begin{array}{l}\text { Skylights } \\
\text { and side }\end{array}$ & $\begin{array}{l}\text { Ellipse、 } \\
\text { circular }\end{array}$ & \\
\hline & $\begin{array}{l}\text { Gymnasium of Northeast } \\
\text { Agricultural University }\end{array}$ & Small-scale & 16000 & - & - & $\begin{array}{l}\text { Skylights } \\
\text { and side }\end{array}$ & Diamond & \\
\hline & $\begin{array}{l}\text { Heilongjiang University } \\
\text { Gymnasium }\end{array}$ & Small-scale & 17000 & & 3000 & $\begin{array}{c}\text { Side } \\
\text { window }\end{array}$ & Rectangle & \\
\hline
\end{tabular}

The analysis shows that the basic plane shape of University Gymnasiums in severe cold areas are mostly regular shapes such as rectangle, circle and ellipse, as well as a small number of irregular shapes. Based on the above considerations, this paper constructs a typical information model of University Gymnasium. The scale of University Gymnasium is small and medium-sized, with 3000 seats and 6000 seats respectively. The size of the stadium is about $38 \mathrm{~m} \times 54 \mathrm{~m} 、 32 \mathrm{~m} \times 44 \mathrm{~m} 、 24 \mathrm{~m} \times 26 \mathrm{~m}$ 。 In this paper, using grasshopper parametric modeling, the general model is divided into two cases of medium-sized and small university gymnasium, and the size of medium-sized stadium is selected as $38 \mathrm{~m} \times 54 \mathrm{~m}$, with 3000 seats in the auditorium. According to the seat size (seat width $0.5 \mathrm{~m}$, row spacing $0.85 \mathrm{~m}$ ), the plane size is calculated to be $51 \mathrm{~m} \times 69 \mathrm{~m}$, building height $25 \mathrm{~m}$; The size of the small playground is $32 \mathrm{~m} \times 44 \mathrm{~m}$, with 1500 seats in the auditorium, and its plane size is $42 \mathrm{~m} \times 54 \mathrm{~m}$, and the height is set at $15 \mathrm{~m}$. According to the design code for sports buildings ${ }^{[7]}$, the starting height of the auditorium stands is about $2 \mathrm{~m}$, and the slope angle of the stands is between $28^{\circ} \sim 30^{\circ}$.

\subsection{Parameter setting of natural lighting and energy consumption simulation}

\subsubsection{Setting of natural lighting parameters}

Effective natural lighting intensity is an important index to evaluate indoor lighting effect. In this paper, the daylight simulation system module of honeybee tool is used to simulate the natural daylighting experiment. The effective natural daylighting intensity in the year-round dynamic evaluation daylighting simulation is used as the evaluation standard of natural daylighting experiment simulation. The concept is to meet the target space illumination demand in a period of time in the test plane as a percentage of the whole year. The acceptance range of illumination is generally defined as 100lux $\sim 2000$ lux.
The main function of University Gymnasium is daily class and training. According to the standard for lighting design of buildings (GB 50034-2013), the required illumination of University Gymnasium in daily training is 300lux, so the effective illumination in this paper needs to be adjusted to the minimum value of 300lux(hereinafter referred to as udi300) during training.

(1) Lighting test point setting

As shown in Figure 2, the test method of light environment in software simulation is the same as the physical test method of light environment. The square grid composed of test points needs to be set in the sports ground part of the model, so the distance between each test point is $2 \mathrm{~m}$, and the height of test plane is $1.67 \mathrm{~m}$.

(2) Reflectivity setting of enclosure interface

In order to achieve the real indoor natural lighting effect, in the natural lighting simulation experiment, it is necessary to set the reflectivity of transparent materials and materials in the building in honeybee. According to the Architectural Lighting Design Manual, the reflectivity of roof, wall, ground and glass in the general model of University Gymnasium is set as $0.8,0.5,0.2$ and 0.6 respectively.

(3) Natural lighting simulation experiment process

Finally, the external shape of the building, climate and enclosure interface material information are input into the main simulation engine, and the UDI value data group is obtained through simulation. The data group is the percentage of the illumination time of each lighting test point in a year to meet the daylighting evaluation index, that is, the corresponding UDI value of each test point. Finally, the average value of the data group is taken for comparison.

\subsubsection{Building energy consumption parameter setting}

The energy consumption of University Gymnasium Building generally comes from the power consumption and building heat consumption of daily classes, training, 
competitions, air conditioning, fans, lamps and other equipment. The total power consumption includes the power consumption of artificial lighting and the operation of some equipment. Therefore, in this paper, we mainly focus on the energy consumption of cooling in summer, heating in winter, artificial lighting and other equipment operation in cold regions, and count the total energy consumption and energy consumption per unit area as the evaluation index of energy consumption.
(1) Thermal parameter setting

In this paper, Shenyang City is selected as the simulation site, according to its building climate zoning, and with reference to the "design standard for energy efficiency of public buildings" (GB 50189-2015). The general model of this paper is set according to the design standard of Low-E double-layer glass curtain wall, and the relevant setting parameters and simulation settings of external wall, roof and window are shown in Table 2.

Table2. Thermal parameters

\begin{tabular}{|c|c|c|c|}
\hline Position & $\begin{array}{c}\text { Heat transfer coefficient } \\
\left(\mathrm{W.m} \mathrm{m}^{-2}\right)\end{array}$ & $\begin{array}{c}\text { Solar heat gain } \\
\text { coefficient }\end{array}$ & $\begin{array}{c}\text { Visible light } \\
\text { transmittance }\end{array}$ \\
\hline Exterior wall & 0.43 & & \\
\hline Roofing & 0.35 & & 0.4 \\
\hline Outer window & 2.00 & & 0.45 \\
\hline
\end{tabular}

(2) Indoor environment setting

a. Air conditioning parameter setting

Referring to the relevant parameters of air conditioning design manual, the design temperature of indoor air conditioning in summer and winter of University Gymnasium is set at $26{ }^{\circ} \mathrm{C}$ and $20{ }^{\circ} \mathrm{C}$ respectively. According to the climate and temperature characteristics of Shenyang area, the cooling time in summer is set from June 1 to August 31, and the heating time in winter is set from November 1 to March 31 of the next year. During the transitional season, natural ventilation is used for adjustment.

b. Human factor parameter setting

The utilization mode of University Gymnasium is very different from that of conventional gymnasium. In terms of operating time, the university gymnasium can be described as a full-time operation, with very high use efficiency. From Monday to Friday, it is used by university teachers and students in class all day, and provides fitness activities for students on weekends and evenings. In this paper, the maximum indoor personnel density is 0.4 person $/ \mathrm{m}^{2}$, the average metabolic capacity is $120 \mathrm{~W} /$ person, the equipment density is $8 \mathrm{w} / \mathrm{m}^{2}$, and the lighting load density is $15.0 \mathrm{w} / \mathrm{m}^{2}$.

(3) Energy consumption simulation experiment process

In the same process as the natural lighting simulation experiment, the external shape of the building, the information of climate and enclosure interface materials, and the information of building indoor environment are input into the main simulation engine. Through the simulation, the energy consumption data of heating, cooling, lighting, fan heat pump and other equipment of University Gymnasium is obtained, and the energy consumption data are accumulated together, and the total energy consumption of the whole year and the energy consumption per unit area of the building can be obtained through calculation.

\section{Coupling simulation analysis of natural lighting and energy consumption}

\subsection{Simulation method of natural lighting and energy consumption coupling research}

The natural lighting and energy consumption simulation is modeled by grasshopper under rhino platform, and the skylight and side windows of University Gymnasium are simulated. In the "Design Standard for Energy Efficiency of Public Buildings", it is stipulated that the area of transparent part of building roof should not be greater than $20 \%$ of the roof area, and the area ratio of single facade window to wall (including transparent curtain wall) of Class A public buildings should not be greater than 0.6. Therefore, the window wall ratio of University Gymnasium side interface is set as $0 \sim 0.6$, the growth gradient is 0.05 , and the south facade is as shown in the table; The window to wall ratio of skylight is $0 \sim 0.2$, and the growth gradient is 0.02 .

Then, using the genetic algorithm in the octopus calculator, and the parameter settings are shown in the table below. Through the continuous combination of various parameter variables, similar to the exchange and variation of gene fragments in genetics, the "individual" is a random combination of many parameter variables. Through the selection of building performance evaluation indicators (survival of the fittest), the variable parameter group that ultimately meets the conditions is obtained; After that, the Pareto economics is used to calculate the optimal solution of many parameters that meet the conditions. The parameter settings of octopus are shown in Table 3.

Table3. Octopus parameter setting

\begin{tabular}{|l|l|l|l|l|}
\hline Elitism & $\begin{array}{l}\text { Mutation } \\
\text { Probability }\end{array}$ & Mutation Rate & Crossover Rate & Population Size \\
\hline 0.5 & 0.2 & 0.9 & 0.8 & 50 \\
\hline
\end{tabular}




\subsection{Simulation experiment of natural lighting and energy consumption coupling research}

In the experimental evaluation index, the minimum value of natural lighting is udi300 $>75 \%$, and the energy consumption per unit area is the minimum value by default, that is, the minimum energy consumption. Considering that the main function of University Gymnasium is divided into daily training in class and taking into account the needs of competition, this paper discusses two cases separately.

\subsubsection{Simulation experiment of natural lighting and energy consumption coupling research under training mode}

(1) Experimental simulation results of gymnasium in medium sized Universities

This iteration has a total of 50 generations. After 125 hours of calculation, the results in the panel tend to be stable, and the results are convergent enough. The solution distribution is shown in Figure 1.
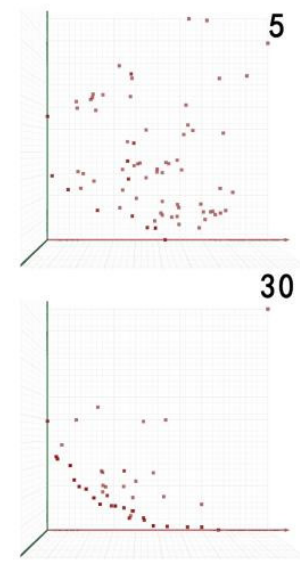

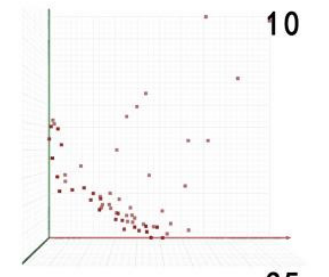

35

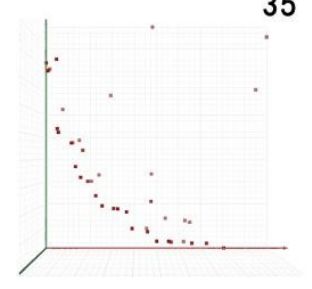

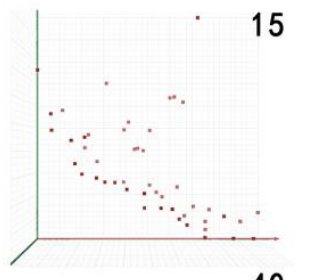

40

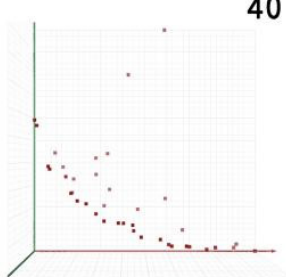

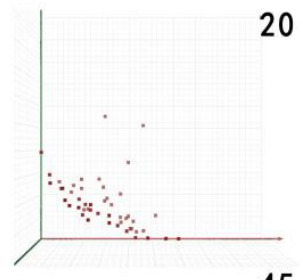

45

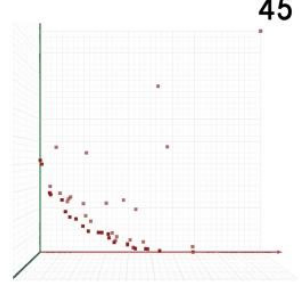

25

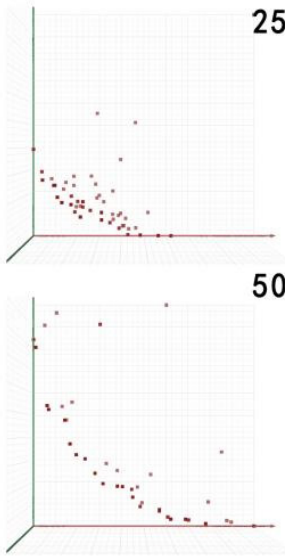

Figure 1. Solving distribution (medium)

(2) Experimental simulation results of small after 125 hours of calculation, the results in the panel tend University Gymnasium Similarly.

to be stable, and the solution distribution is shown in Figure 2.

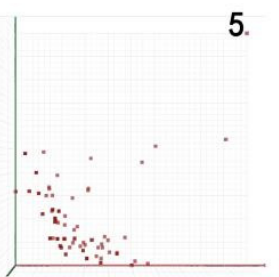

30

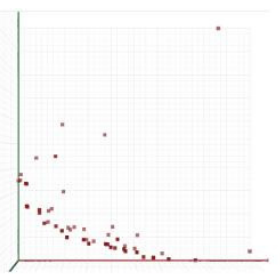

10

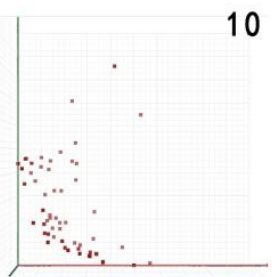

35

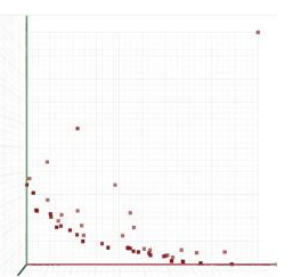

15

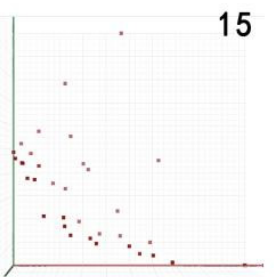

40

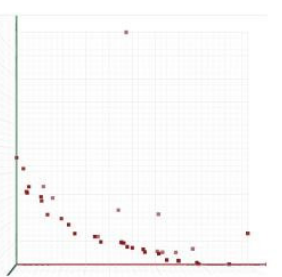

20

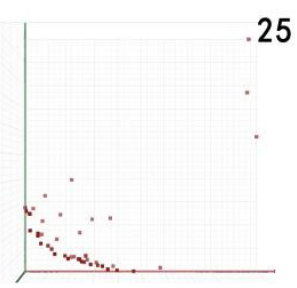

45

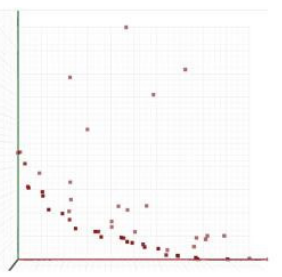

50

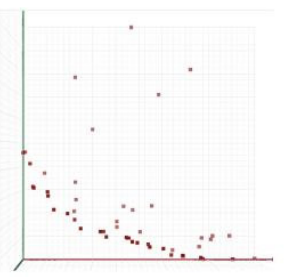

Figure 2. Solving distribution (small)

\section{Natural lighting and energy saving design strategy}

(1) In the coupling optimization design of natural lighting and energy consumption of medium-sized university gymnasiums, the 50th generation optimal solution analysis shows that the lighting mode should adopt side window lighting, mainly South lighting, or supplemented by less East, West and North lighting, so as to obtain the minimum energy consumption and better effective illumination design values, such as figure 3(a) and (b); In addition, North lighting can be used as the main lighting, while East, West and South lighting can be used as auxiliary lighting, so as to obtain the optimal effective illumination and less energy consumption design values, such as figure 3 (c) and (d).

The following are some of the optimal non-dominated solution sets in medium-sized University Gymnasiums: 
Table4. Optimal non dominated solution set (medium)

\begin{tabular}{|c|c|c|c|c|c|c|c|}
\hline Number & $\begin{array}{c}\text { Window to } \\
\text { wall ratio } \\
\text { (East) }\end{array}$ & $\begin{array}{c}\text { Window to } \\
\text { wall ratio } \\
\text { (South) }\end{array}$ & $\begin{array}{c}\text { Window to } \\
\text { wall ratio } \\
\text { (West) }\end{array}$ & $\begin{array}{c}\text { Window to } \\
\text { wall ratio } \\
\text { (North) }\end{array}$ & $\begin{array}{c}\text { Window to } \\
\text { wall ratio of } \\
\text { skylight }\end{array}$ & $\begin{array}{c}\text { UDI } \\
(300)\end{array}$ & $\begin{array}{c}\text { Energy consumption } \\
\text { per unit area } \\
\left(\mathrm{kWh} / \mathrm{m}^{2}\right)\end{array}$ \\
\hline 1 & 0 & 0.45 & 0 & 0 & 0 & 57.3 & 133.3 \\
\hline 2 & 0 & 0.25 & 0.05 & 0.05 & 0 & 69.4 & 135.1 \\
\hline 3 & 0.05 & 0.1 & 0.05 & 0.2 & 0 & 83.9 & 140.8 \\
\hline 4 & 0.05 & 0.05 & 0.05 & 0.3 & 0 & 85.3 & 145.6 \\
\hline
\end{tabular}

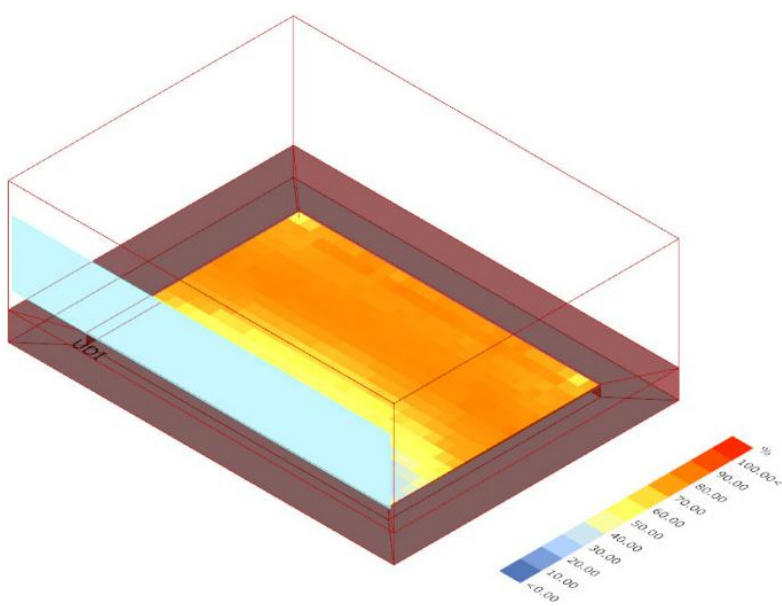

(a)

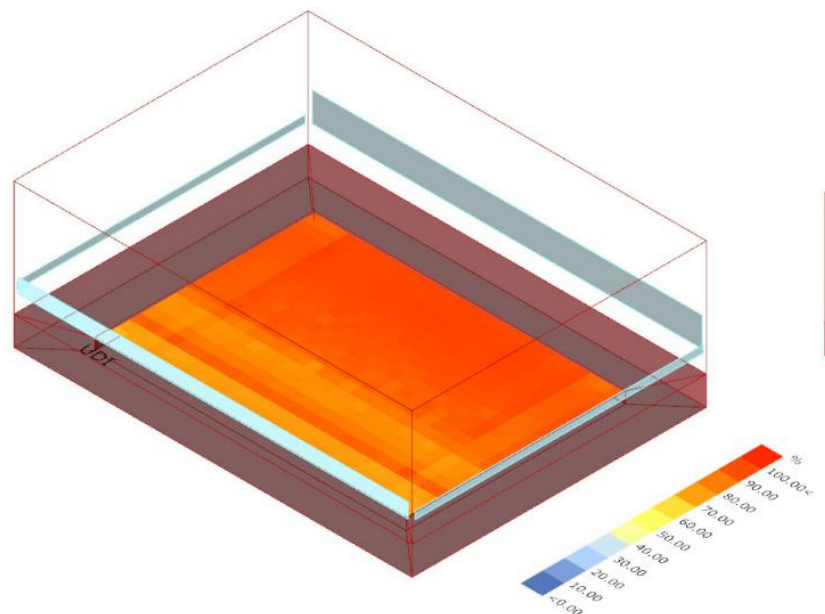

(c)

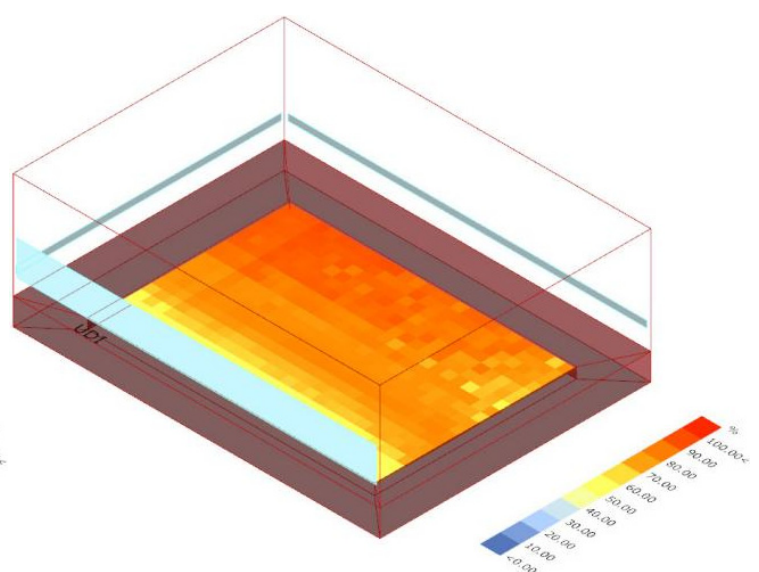

(b)

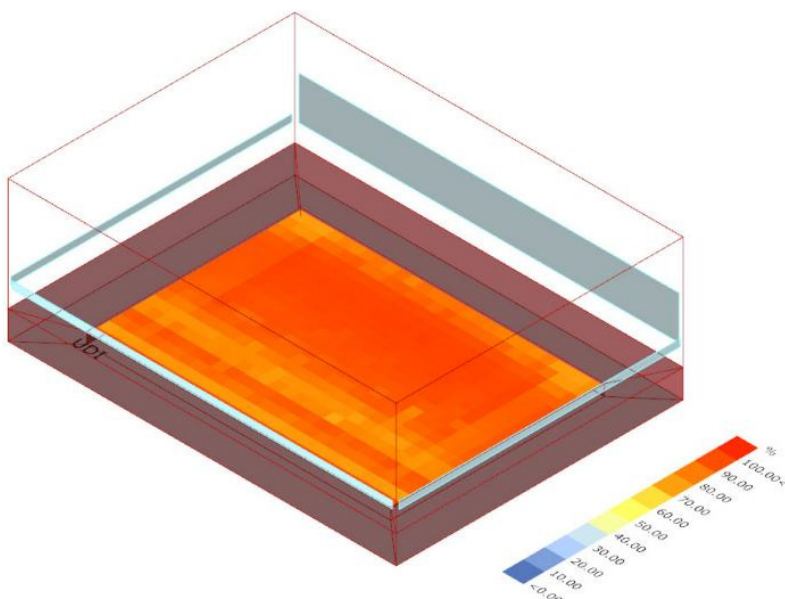

(d)

Figure 3. Effective illumination photothermal map (medium)

(2) In the coupling optimization design of natural lighting and energy consumption of small university gymnasium, the 50th generation optimal solution analysis shows that the side window lighting should be adopted in the lighting mode, with the South lighting as the main lighting mode and the East, West and North lighting as the auxiliary. The minimum energy consumption and better effective illumination design values can be obtained, such as figure 4（a） and (b) ; It can also be mainly North lighting, supplemented by East, West and South lighting, which can obtain the optimal effective illumination and less energy consumption design values, such as figure 4 (c) and (d).

The following are some of the optimal non-dominated solution sets in small University Gymnasiums:

Table5. Optimal non dominated solution set (small)

\begin{tabular}{|c|c|c|c|c|c|c|c|}
\hline Number & $\begin{array}{c}\text { Window to } \\
\text { wall ratio } \\
\text { (East) }\end{array}$ & $\begin{array}{c}\text { Window to } \\
\text { wall ratio } \\
\text { (South) }\end{array}$ & $\begin{array}{c}\text { Window to } \\
\text { wall ratio } \\
\text { (West) }\end{array}$ & $\begin{array}{c}\text { Window to } \\
\text { wall ratio } \\
\text { (North) }\end{array}$ & $\begin{array}{c}\text { Window to } \\
\text { wall ratio of } \\
\text { skylight }\end{array}$ & $\begin{array}{c}\text { UDI } \\
(300)\end{array}$ & $\begin{array}{c}\text { Energy consumption } \\
\text { per unit area } \\
\left(\mathrm{kWh} / \mathrm{m}^{2}\right)\end{array}$ \\
\hline 1 & 0 & 0.35 & 0 & 0.05 & 0 & 66.5 & 118.9 \\
\hline 2 & 0.05 & 0.2 & 0.05 & 0.1 & 0 & 78.0 & 120.8 \\
\hline 3 & 0 & 0.1 & 0 & 0.3 & 0 & 85.0 & 125.2 \\
\hline 4 & 0.05 & 0.1 & 0.05 & 0.35 & 0 & 86.8 & 126.5 \\
\hline
\end{tabular}




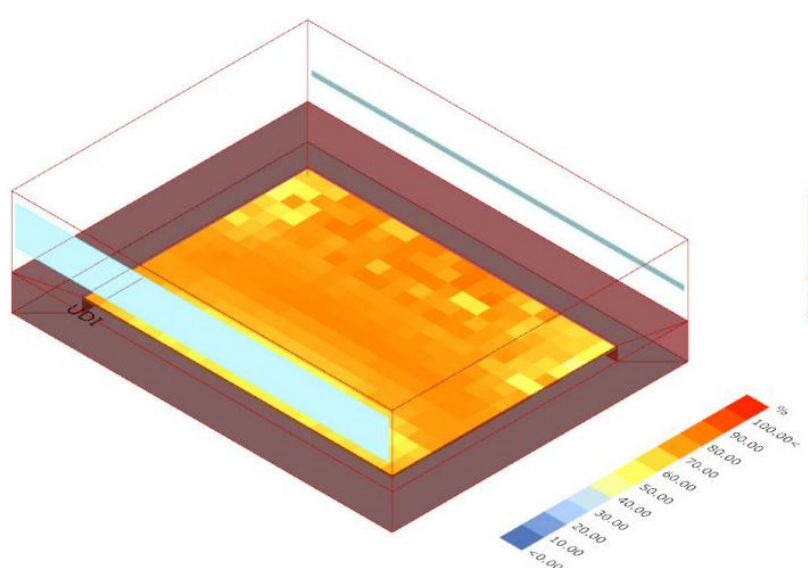

(a)

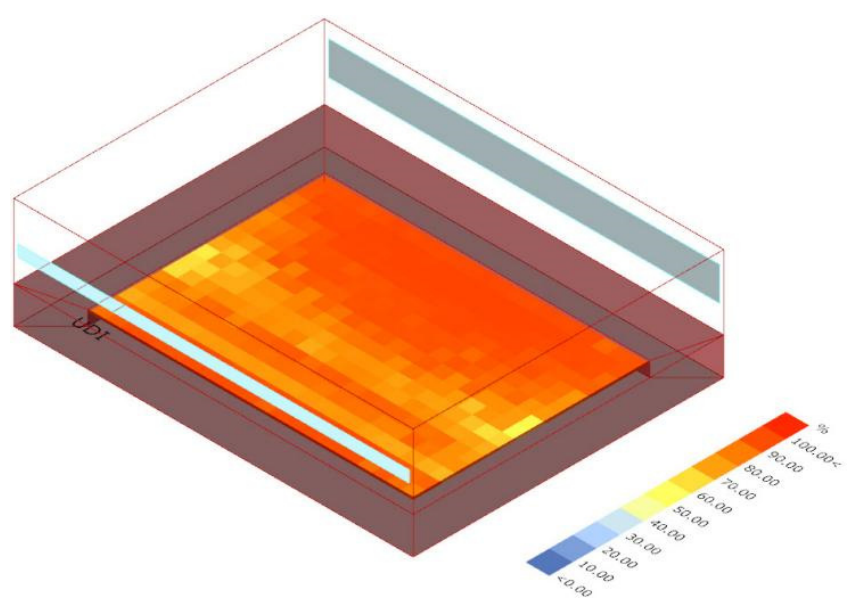

(c)

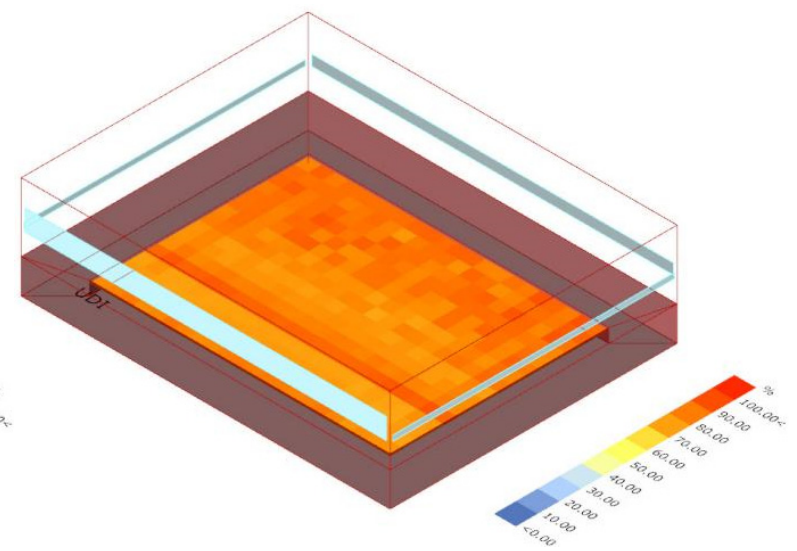

(b)

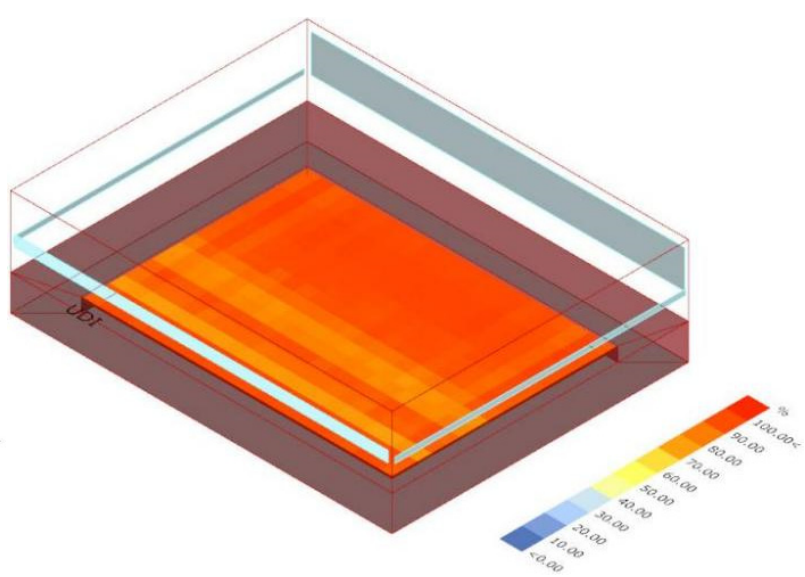

(d)

Figure 4. Effective illumination photothermal map (small)

\section{Conclusion}

Under the background of building energy conservation and emission reduction, the construction of low energy consumption and high comfort University Gymnasium is the general trend. It is more and more important to apply multi-objective optimization design to solve the coupling problem of natural lighting and energy consumption. Based on the sampling survey of University Gymnasium Building, this paper summarizes its basic form, establishes the double objective optimization model of natural lighting and energy consumption by using digital simulation technology, obtains the window opening scheme with consideration of natural lighting and low energy consumption through experiments, reveals its influence law, and summarizes the window opening design strategy of University Gymnasium Building, It provides theoretical basis and design reference for multiobjective performance optimization of large space buildings in cold regions.

\section{Acknowledgments}

This paper was completed under the careful guidance of Mr. Zhang Longwei. From the topic selection of the paper, to literature research and data collection, and then to case research, it helped me build up confidence and firm intention to overcome difficulties when I encountered difficulties. I benefited a lot from the profound knowledge and rigorous teaching attitude of Mr. Zhang Longwei.I would like to express my heartfelt thanks to all the teachers, seniors, friends and family members who have helped me.

The authors gratefully acknowledge the support of National Natural Science Foundation of China (Grant 51978418, 51738006) and Scientific Research Plan of the Educational Department of Liaoning Province(Grant lnjc202003).

\section{References}

1. Liu Ying. Research on natural light environment design of gymnasium based on value engineering theory [D]. Harbin Institute of technology, 2010.6

2. Bai Xinyu. Preliminary study on light environment evaluation index system of main space of University Gymnasium [D]. Green environmental protection building materials, July 2017

3. Song Zefang, Zhou Yihu. University campus planning and architectural design [M]. China 
Construction Industry Press, 2006.9.1[4]Zhang Jian. Study on the influence of building orientation and height on the ventilation behavior of office users $[\mathrm{J}]$. Huazhong architecture, 2011, 29.8

4. Zhang Bin. Study on the optimization design of natural light environment of urban residential buildings in Beijing [d]. Harbin: Harbin University of technology, 2010

5. Liu Yao. Balance judgment of natural lighting and air conditioning energy consumption in public area of large space of railway station [D]. Chengdu: Southwest Jiaotong University, 2015

6. Sun Cheng, Han Yunsong, Zhang Bin, et al. Building of office building environment information model in severe cold area [j]. New building, 2015

7. Ministry of construction of the people's Republic of China. Jgj31-2003 code for design of sports buildings [S]. China Construction Industry Press, 2003.10.01 